IZA DP No. 8003

Can the UAE Avoid the Oil Curse by Economic Diversification?

Ilham Haouas

Almas Heshmati

February 2014 


\title{
Can the UAE Avoid the Oil Curse by Economic Diversification?
}

\author{
Ilham Haouas \\ Abu Dhabi University \\ Almas Heshmati \\ Sogang University \\ and IZA
Discussion Paper No. 8003
February 2014 \\ IZA \\ P.O. Box 7240 \\ 53072 Bonn \\ Germany \\ Phone: +49-228-3894-0 \\ Fax: +49-228-3894-180 \\ E-mail: iza@iza.org
}

Any opinions expressed here are those of the author(s) and not those of IZA. Research published in this series may include views on policy, but the institute itself takes no institutional policy positions. The IZA research network is committed to the IZA Guiding Principles of Research Integrity.

The Institute for the Study of Labor (IZA) in Bonn is a local and virtual international research center and a place of communication between science, politics and business. IZA is an independent nonprofit organization supported by Deutsche Post Foundation. The center is associated with the University of Bonn and offers a stimulating research environment through its international network, workshops and conferences, data service, project support, research visits and doctoral program. IZA engages in (i) original and internationally competitive research in all fields of labor economics, (ii) development of policy concepts, and (iii) dissemination of research results and concepts to the interested public.

IZA Discussion Papers often represent preliminary work and are circulated to encourage discussion. Citation of such a paper should account for its provisional character. A revised version may be available directly from the author. 
IZA Discussion Paper No. 8003

February 2014

\section{ABSTRACT}

\section{Can the UAE Avoid the Oil Curse by Economic Diversification?*}

Recent research conclude that the GCC economies have failed to address the oil curse. They are far behind other countries, especially those in the G7, which possess huge reserves of oil wealth but have undertaken economic diversification to correct the ill-effects of an oil curse. This paper takes an in-depth look into the UAE economy as a model but also as a reminder of the struggles ahead. The findings support the fact that the UAE is facing an oil curse. Declining levels of total factor productivity, GDP volatility, negative returns on investment, and a labor force that is too reliant on government's supply of jobs are among the many reasons that support the thesis. The UAE has made good progress in recent years to diversify its economy. However, the drivers of economic growth in the UAE are vulnerable to external shocks outside of the Emirate's control. It is now critical that the UAE take steps to mitigate economic disruptions that might result from these shocks. In this case study the UAE economic performance is examined, and a data-driven roadmap for sustainable growth is suggested. The analysis shows that greater efforts are needed to stimulate the diversification of the production base by encouraging increased domestic, especially private, investment. Well-targeted policies should be adopted to accelerate reform and facilitate the involvement of the private sector in the economy.

JEL Classification: C22, E20, L16, L71, O11, O53

Keywords: $\quad$ growth accounting, TFP, oil curse, economic diversification, UAE

Corresponding author:

Almas Heshmati

Department of Economics, Room K526

Sogang University

35 Baekbeom-ro

Mapo-gu, Seoul 121-742

Korea

E-mail: heshmati@korea.ac.kr

\footnotetext{
* This paper is a part of a project financed by the Economic Research Forum (ERF). The authors received excellent research assistance provided by Dantes $D$. which is gratefully acknowledged. The authors would like also to thanks Mrs. R. Radwan and Dr. Babweva, M. for their comments and suggestions on an earlier version of this paper.
} 


\section{Introduction}

The United Arab Emirates (UAE) is a federation of seven different emirates which together comprise the third largest economy in the Middle East, after Saudi Arabia and Iran. Its per capita GDP is second only to Qatar. UAE GDP growth has averaged about $5 \%$ per annum, but has oscillated from negative to positive throughout the years as dictated by oil prices. The UAE is an important producer of natural gas and oil, ranking seventh globally in total proven reserves of both. Abu Dhabi, the country's capital and also the largest emirate in the federation, possesses the majority of oil and natural gas reserves followed by Dubai, with small amounts in Sharjah and Ras Al-Khaimah. The country is also a member of the Organization of Petroleum Exporting Countries (OPEC) $)^{1}$.

Much of the UAE's improved economic performance over the recent years is a result of positive steps taken to diversify its economy. Generally, non-oil GDP has sustained positive growth rates but without high volatility like the oil sector. As this case study later shows, the growth in goods and services sectors is establishing a greater share in GDP, which has stabilized the aggregate GDP growth rate. The economic volatility resulting from the oil wealth is being offset by positive productive returns from greater economic diversification.

The prosperity of the UAE and its rapid transformation into a booming economy has been made possible by revenues from oil exports. Its resource wealth has contributed to its overall growth; specifically, a rise in oil export prices led to improvements in the terms of trade determinants of the growth rate formula. However, the oil wealth is not the only factor; the macroeconomic stability and financial development of the UAE cannot be ignored.

High oil prices strengthened the key macroeconomic indicators in the UAE. Recent empirical literature suggests that the income from oil production is more likely to have a negative development impact and, in the extreme case, it could lead to a decline in oil income at the end of the boom. The oil windfall actually slowed attempts to address some of the challenges while the global financial crisis has reminded policymakers that structural challenges must be addressed at a time when macroeconomic conditions are favorable and not when the economies are slowing down. (Elhiraika and Hamad, 2007)

However, the drivers of economic growth for the UAE are vulnerable to external shocks outside of the Emirate's control as a result of the global economic slowdown. The objective of this paper is to answer the following questions: (a) what role has economic diversification played in the UAE's economic growth? and (b) what is the cost of avoiding the oil curse?

In this paper we address the main policy questions, such as the diversification of the UAE economy, and the decline in total factor productivity (TFP) growth. Diversification has been the most important challenge for the country in the last decade. Human capital, labor distribution, privatization vs. public spending, and productive investments are among the factors that must be considered when planning to diversify the UAE economy in order to reduce the country's dependence on the resource wealth to achieve overall economic growth.

\footnotetext{
${ }^{1}$ For a comprehensive report on Abu Dhabi economic vision 2030 and its areas of economic policy, see reports by Abu Dhabi Council for Economic Development and the Department of Planning and Economy, November 2008.
} 
We will also analyze the decline in total TFP growth and the Emirate's labor problem. The analysis will show that the Emirate's growth rate has been impacted by decreasing marginal rates of return on capital from unproductive investments that resulted from higher oil rents. The UAE should invest more resources on promoting structural growth in non-oil sectors. Low labor productivity can be addressed by shifting towards a better skilled domestic labor supply. The large influx of unskilled foreign labor has created a labor force that is not able to sustain productive growth. Although the lure of cheap foreign labor is an incentive to create more labor intensive private investments (Ministry of Labor 2000), the UAE government must focus on human capital investment in education and training, in order to stimulate economic growth.

The rest of this study is organized as follows: In Section 2, we discuss the overview of the UAE's economic performance. A regression model of the determinants of growth in the UAE is then specified and estimated in Section 3. In order to support the aggregate growth, a determinant of diversification model is used in Section 4 to measure the impact of particular areas under structural reform. A description of a balancing act is presented in Section 5. Finally Section 6 concludes with some policy remarks.

\section{An Overview of the UAE's Economy}

The UAE has taken steps in the right direction in recent years to diversify its economy. The share of the country's revenue from export of oil has decreased relative to the revenue from the non-oil sectors. In fact, the Institute of International Finance (IIF) stated in its October 2013 report that it sees favorable prospects for the GCC countries. The IIF cites continued robust growth in trade, tourism and transportation, coupled with higher government capital spending as strong growth drivers in 2013. Our most recent analysis discovers that UAE oil exports hit a record high in 2012 to $\$ 125$ billion, which is 5\% higher than the previous yearly record revenue (Garbis and Abed, 2013). The Emirates economy is less vulnerable to the volatile world oil market prices as non-oil sectors show signs of growth (Fasano, 2002).

Following its brief economic recession in the year prior, related to the global economic crisis, the UAE returned to surplus in 2010. However, the drivers of economic growth do not withstand the external shocks of the global economic slowdown. The UAE's pro-cyclical fiscal policy exacerbates the economic cycle. Before the recession, the Central Bank increased liquidity. As part of monetary stimulus measures, the Central Bank continued to expand liquidity and accumulate large foreign assets, thereby increasing the money supply. Inflationary pressures resulting from high commodity prices and global economic slowdown could harm the UAE economy. A lax monetary policy to encourage domestic investment while decreasing domestic savings could also backfire. The IMF warns of an increase in to around 3\% in the next two to three years, and, to top it all, the oil curse remains. It is time for the UAE to face up to this fact (Article IV Consultation, IMF 2011).

The argument is strengthened even further as we examine the period during the 1970s through 1980s, when the UAE experienced a period of high growth. The UAE government used surplus oil revenue for infrastructure and structural growth. However, this period of rapid growth hit a major inflection point to the downside brought about by lower oil prices. In the mid-1980s, the UAE experienced declining economic growth and high inflation. From 1975-1999, the economy had a volatile performance resulting 
from a high population growth, spurred mainly by a wave of immigration. The rapid increase in population was not productive as the per capita income declined along with total factor productivity. (Elhiraika and Hamad, 2007)

Nevertheless, the UAE economy is fairly stable. It is among the Top 43 High Income Countries judged by the Human Development Index. Its income is reliant on both oil and non-oil sectors. Despite having a high concentration of economic activity in the oil sector, non-oil aggregate GDP exceeds the crude-oil sector. In fact, the share of oil revenue in the UAE has decreased from $70 \%$ in 1970 to $40 \%$ in the 1990 s. This is brought about by UAE government's efforts to diversify its economy ${ }^{2}$.

Policies executed during this period of diversification and economic growth were meant to encourage private investment and domestic productivity. "The bulk of domestic investment in the 1990s went to the construction and real estate sector, followed by the transport and communication sector and manufacturing. Meanwhile, as percent of total investment, investment in the oil sector was almost halved in the 1990s.” (Elhiraika and Hamad, 2007) ${ }^{3}$.

Figure 1: Less Reliant on Petrol: Private and Petrol Investments

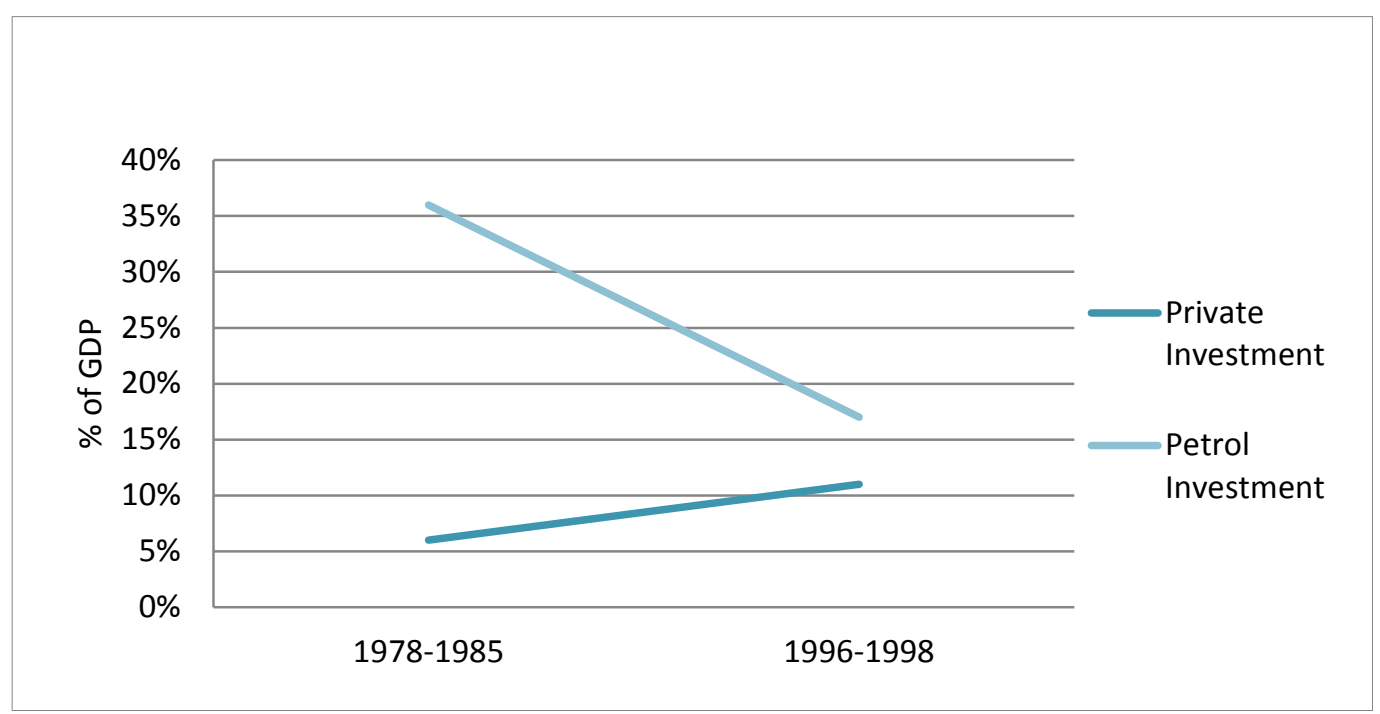

Source: Ministry of Planning (1998)

We find that public investment is not productive due to decreasing marginal rates of capital return. This is a result of skewed investments in and out of the oil sector. These investments made by the government are channeled towards infrastructure services and some structural development. The area that demands greater attention is thus the promotion of private investment. Figure 1 shows that the share of private investment has increased while that of petrol investment has decreased. This is a

\footnotetext{
${ }^{2}$ Data used here support the idea how the UAE has turned oil curse into blessing. See Fasano (2002).

${ }^{3}$ Data here shows that the UAE is taking steps to decrease its dependence on the oil sector. As oil wealth increased, the total investment in non-oil sectors has also increased. The hope is that a comfortable balance will be reached to realize the goal of diversification. Findings supported by: Elhiraika, A.B. and Hamed, A. H. (2007): "Explaining Growth in an Oil-Dependent Economy: The case of The United Arab Emirates", in J. Nugent and H. Pearson (eds.), Explaining Growth in the Middle East North Holland/Elsevier.
} 
remarkable finding that supports the need for diversification, which this paper will explore further.

Also addressed is the increasing labor problem in the UAE. Immigrant labor is cheap and accessible. However, the state managed influx of workers entering the UAE from abroad crowds out the domestic labor force. Although the domestic rates of secondary education enrollment have increased, there is low labor productivity and a heavy reliance on government supply of labor to cater to the needs of the UAE. There needs to be a shift towards a better skilled domestic labor supply that demands reasonable wages from the private sector. (Ministry of Labor, 2000)

\section{Total Factor Productivity and Growth Accounting}

The real challenges arise in the state of TFP. GDP growth is comprised of growth in labor, capital, and productivity. In the UAE, oil rents have led to an increased use of labor and capital resources. However, this analysis explains that a decreasing marginal rate of capital return resulting from oil rents have contributed to the skewed investments which is evident in the growth rate. Instead of using oil rents for the purpose of increasing the oil wealth, the UAE should focus more on resources promoting structural growth in the non-oil sectors. The positive and higher returns on these investments would contribute to TFP. In reality, low productivity projects equate to low capital efficiency in oil sectors and are left vulnerable to price swings. Thus, as a result of non-optimal investment, TFP in the UAE has declined by 32\% (Elhiraika and Hamad, 2007) during the past years.

The decline in TFP raises the serious concern that the UAE, like its oil producing neighbors, is experiencing an oil curse. Put briefly, the dependency on oil results in low productivity. In order to correct this anomaly, the UAE must focus on effectively distributing oil rents to non-oil sectors while promoting structural growth such as skilled labor to be used in a more diversified economy. The sections below analyze the determinants of growth by modeling an overall growth rate index to help determine the areas where resources need to be concentrated.

The need to figure out how to best allocate resources is imperative, given past mistakes. For example, Venezuela has wasted its oil wealth to the point that the average Venezuelan nowadays has an income that is only 25\% of what it was in 1950 (Stanley and Bunnag, 2001). In Sudan, rent appropriators resisted reform while TFP experienced a broad decline brought on by inflation (Hammouda, 2006). The UAE can get this right; fortunately, significant steps have been taken to diversify its economy.

\subsection{Total Factor Productivity Framework}

To determine the productivity of capital and labor, and its efficient utilization as part of total output, a decomposition of aggregate GDP growth is computed. The overall GDP is broken down into labor, capital, and productivity components. Because TFP is not explained by growth in factor inputs as part of GDP, it is instead defined by technical progress. By first assuming constant returns to scale, competitive markets, and neutral technical progress, the neoclassical production function is then used to determine the productivity of inputs to total output growth (see Solow, 1956). The production model and estimated growth rate is written as:

$$
Y=A K^{\alpha} L^{(1-\alpha)} \text {, and }
$$




$$
\dot{Y}=\dot{A}+\alpha \dot{K}+(1-\alpha) \dot{L}
$$

The neoclassical production function in equation (1) defines $\mathrm{Y}$ as the rate of output. A represents the total factor productivity growth rate (TFPG). The elasticity of output $\alpha$ equals the capital income share defined by the ratio of $\mathrm{K}$ to $\mathrm{L}$. The $\dot{Y}, \dot{K}$ and $\dot{L}$ in equation (2) denote the growth rate of output, capital formation, and labor use, respectively.

In this section, it is explained that human capital is defined by the years of schooling, but note that this does not represent a productive labor market. The neoclassical production function provides a strict measure of labor and capital contributions to output. An analysis of the growth rates of capital and labor, judged by their share of contributions to total output, provides a more accurate measure of TFPG. On application of the UAE economic data from 1974 to 2007, the production function in (2) provided the growth illustrated in Figure 2.

Figure 2: UAE Growth Analysis and its decomposition, 1974-2007

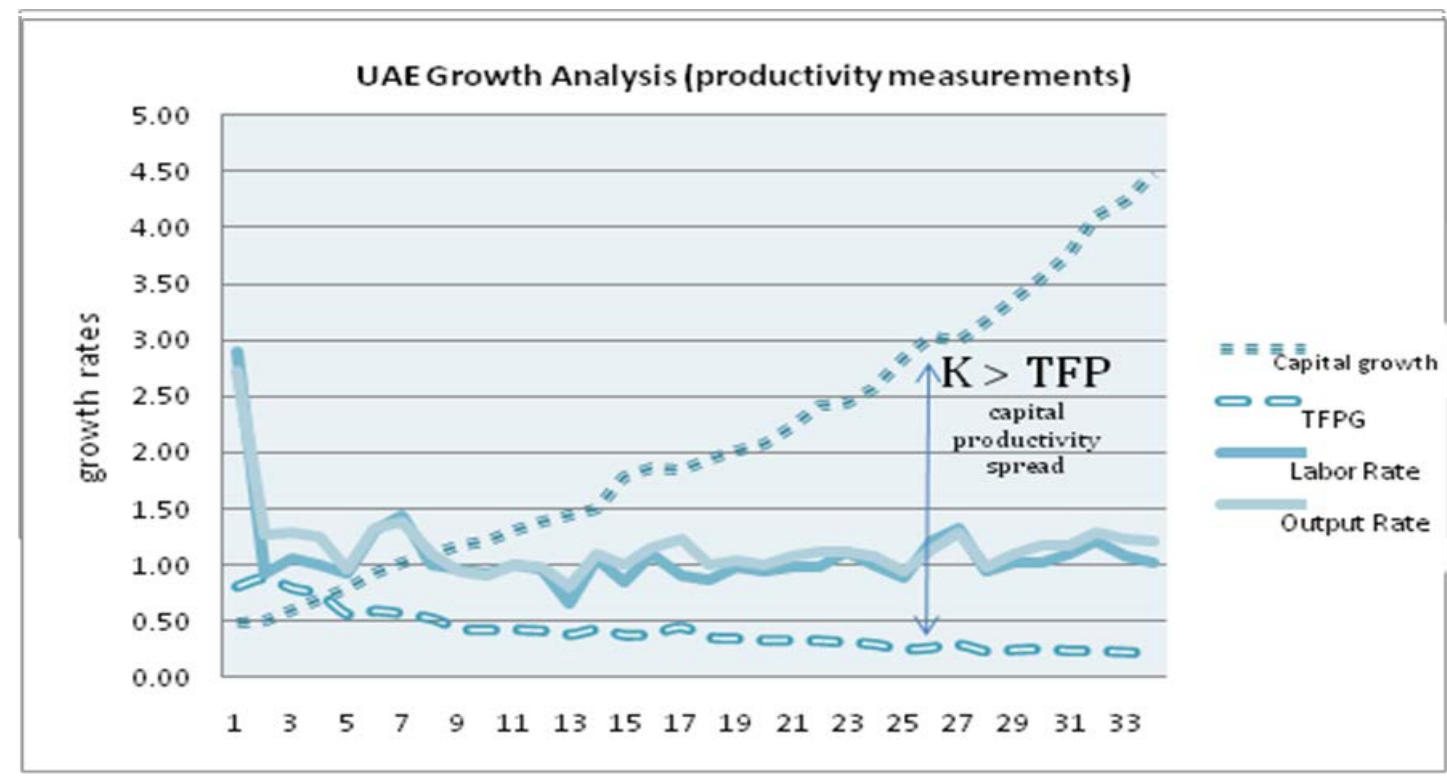

Year 1974

To year 2007

Source: Authors' calculations.

The findings from the neoclassical production function illustrated in Figure 2 show that there is a clear capital productivity spread. Gross capital formation is rapidly increasing, while TFP oscillates around $0.50 \%$ and then continues a slight decline entering the year 2000 and beyond. It is evident that capital is not being used efficiently, and productivity is declining as a result. Thus, the oil wealth, being the basis of UAE income capital, is too concentrated in the high value sector. Therefore, it does not result in an effective output and an overall high rate of productivity. Overall GDP growth is engulfed by capital and investments, but it does not accurately show the problems of the oil curse and its effects in the form of low productivity. A deeper analysis such as the current one, very likely accurately sheds light on the nature of the problem and its explanations. 
According to Bisat et al. (1997), increasing productivity is not an important source of growth in some Arab nations. This is a result of economic policies and external shocks that must be considered in addition to the quantitative results. The UAE economy favors investments that are not conducive to TFPG. As this section will consistently explain, investment is associated with decreasing marginal rates of return due to the low concentration on the productive sector in the UAE. Subsidies and price distortions create bias in investments, therefore skewing the excessive concentration of capital, producing inefficiency. There is a fine line between investments by the UAE government and investments by the private sector. Labor plays an important role in determining the form of investment which yields more efficient results ${ }^{4}$.

According to the Ministry of Labor Report (2000), there is a large influx of low skilled foreign labor that is not able to sustain high productive growth. The report explains that an alarming 99\% of cheap foreign labor occupies the UAE private sector. The lure of cheap foreign labor is an incentive to create more labor intensive private investments. However, leveraging the abundant immigrant labor yields productive investment in the short-run. As the results of the neoclassical production function shows (Figure 2), labor rates closely follow output rates, signaling an efficient use of labor. Regardless of the short-term productivity, in the long run, private investment from cheap immigrant labor will not contribute to economic growth. The neoclassical production function results show efficiency, but there is no growth in labor or output.

In order to stimulate growth, the UAE government must focus on domestic human capital by investing in education, training, etc. In addition, greater privatization should be encouraged to utilize the better skilled people of the UAE to produce efficient growth. The labor problems will continue to stall TFP and growth. The UAE faces a domestic labor scarcity, as nationals prefer to wait for higher paid government jobs. The government is not able to fully supply jobs for such high demand at comfortably high wages (IMF Consultation, 2009). The resulting unused labor should receive the skills necessary to become an active contributor to the private sector, while receiving competitive wages.

\subsection{Growth Accounting Framework}

The neo-classical growth model is applied to account for the growth of the UAE economy over time. The growth literatures propose many explanatory variables (see Barro, 1991; Gregorio and Guidotti, 1995). Many econometric studies of growth have used cross-country data, but any variables used in these studies are difficult to use in time series regression. The growth accounting framework of this case study works by decomposing aggregate GDP growth into labor, capital, and technical progress components. Total output growth is explained by input growth and technology induced improvement of productive efficiency ${ }^{5}$.

Enhanced econometric models use a number of variables in modeling growth and estimating TFP. However, due to limited data for time series regression analysis and

\footnotetext{
${ }^{4}$ See the Ministry of Labor Report (2000).

${ }^{5}$ Shihab (2000) studied growth accounting with reference to the UAE.
} 
the particular economic environment of the UAE, the selected growth rate serves as the dependent variable and the independent variables are as follows ${ }^{6}$ :

- Gross domestic investment as a ratio of GDP: The theory assumes that the accumulation of gross domestic investment will always produce a positive effect on economic growth. Since the major part of the UAE economy is based on resource industry and its effect is always visible in the short-term, this variable is used to estimate the short term effect on growth.

- Terms of trade: The ratio of export price to import price is measured as terms of trade. Therefore, an increase of terms of trade would undoubtedly stimulate domestic industries that produce export goods, which further simulates the whole economy. By theory, there exists a positive relationship between terms of trade and economic growth.

- Natural resource abundance: This variable usually contributes a negative effect on economic growth due to the theory of 'Dutch disease'. According to this theory, the high price of natural resources will attract the factors from other sectors to flow into the resources sector. In the long run, the economy will rely solely on the resources sector and the growth rate will decrease because of the decrease of marginal rate of return from this single sector. In the UAE, this abundant sector is oil.

- Inflation: According to the rational expectation theory, inflation will cause market participants to expect future price increases, which would jeopardize not only future economic growth, but also the current economic growth. It could affect all sectors in the economy by decreasing savings and investments, and eventually lead to an accelerated depletion of the currency. On the whole, the expectation of future inflation will produce an overall negative effect on the whole economy.

- Changes of incomes of trading partners: This variable will directly stimulate the corresponding export sectors when the income of trading partners increases. The growth of export sectors could stimulate investment, domestic demands, and propel growth in the whole economy. But in light of the characteristics of UAE, there exists inelasticity in the demand for UAE's natural resource exports. Thus, the scale of effect on economic growth is questionable in the case of the UAE.

- Accumulation of human capital: Several theories show a positive relationship between human capital accumulation and economic growth. The input of tangible capital will always show a decrease in marginal rate of return, but employment of human capital and input of $\mathrm{R} \& \mathrm{D}$, could delay the appearance of decrease in marginal rate of return. Thus, the human capital will definitely produce a positive effect on economic growth. However, due to the lack of UAE data, secondary school enrollment rate is used as a proxy to human capital.

Note that there are many other variables, such as bank credit to the private sector, M2 ratio to GDP, and the exchange rate, which could potentially explain the economic growth. Considering the financial environment and capital market of the UAE, and the divergences of the theory, they were not included in the regression model.

\footnotetext{
${ }^{6}$ Following Elhiraika and Hamad (2007) we consider gross domestic investment, terms of trade, natural resource abundance, inflation, changes of income, and accumulation of human capital as independent variables.
} 


\subsection{Econometric Results}

According to the available data on the UAE, the above variables were collected as predictors to explain the economic growth over the period $1970-2007^{7}$. The augmented Dickey-Fuller shows a maximum of 2 lags of economic growth rate. The ARIMA method was used to fit a AR(2) time-series model to interpret the causality of economic growth. The DW test is insignificant in both tails under 5\% significant level, which means there is no significant series autocorrelation under the AR(2) model. Also, all the explanatory variables are significant at the $5 \%$ level and summarized in Table 1.

Table 1: Determinants of growth in UAE, 1970-2007

\begin{tabular}{|l|rr|}
\hline Variable & Coefficient & p-value \\
\hline Intercept & 0.9431 & 0.0004 \\
Investment rate & -2.1762 & 0.0001 \\
Percentage change of terms of trade & 0.8689 & 0.0001 \\
Natural resources abundance & -0.3068 & 0.0146 \\
Inflation & -3.1847 & 0.0023 \\
Income of trading partners & 0.0000813 & 0.0009 \\
Accumulation of human capital & 1.4794 & 0.0219 \\
\hline Adjusted $\mathrm{R}^{2}$ & \multicolumn{3}{|c|}{0.9606} \\
\hline Durbin Watson test & 1.9601 \\
\hline
\end{tabular}

Gross domestic investment as a ratio of GDP resulted in a negative contribution to the overall growth rate. This implies that there is a decreasing marginal rate of capital return associated with the domestic investment in the short run. The results coincide with the original viewpoint that there is inefficient and non-productive investment in the UAE. The UAE should effectively utilize investment to promote the areas of positive contribution to the growth rate as follows:

Terms of Trade has a positive influence $(87 \%)$ on the growth rate. The UAE's abundant factor of oil stimulates the overall growth. Thus, higher oil prices contribute a great amount to the economy. Since oil represents approximately $50 \%$ of the UAE economy, this will be an important variable for growth. An increase in terms of trade will equate to an increase in net exports of oil and aggregate output. This variable is represented by the Oil Price Index.

Natural Resource Abundance has a negative effect on the growth rate. This serves as another support to the fact there are decreasing marginal rates of capital return as the abundant oil resource sector receives greater resource allocation than other non-oil sectors. The Dutch Disease concept plays a significant role in the importance of this variable. Oil, being the abundant natural resource sector, expands at the expense of other non-oil sectors. The fact that it is negative is because of its high sector concentration, leaving the overall economy vulnerable to cyclical shocks, while other non-oil growth areas are abandoned.

Inflation resulted in a negative effect on the overall growth rate. The theory that expectations for future price growth leads to an economic slowdown is supported in

\footnotetext{
${ }^{7}$ Due to unavailability of data, it has not been possible to update the data to cover post 2007/8 global economic crisis.
} 
this model. This will encourage market participants to increase savings and discourage investment to improve the productivity and output of the UAE, thus stalling the growth overall.

Changes in the incomes of trade partners have a positive, but small effect on the growth rate. This is because a greater income equates to a greater purchasing power as trade partners increase their demand for export goods. Generally, higher incomes result in greater use of resources, thereby increasing consumption. However, despite its positive contribution, this variable is a minor factor in the inelastic demand associated with the UAE's prime natural resource exports such as oil.

Human Capital has a positive but small effect on the growth rate. As a matter fact, human capital accumulation of the UAE experienced an increase in the past thirty years and it has been really helpful in stimulating the whole economy, not only by delaying the appearance of decrease in marginal rate of capital return, but also by giving opportunities for growth to the economy.

Figure 3: Growth model’s performance

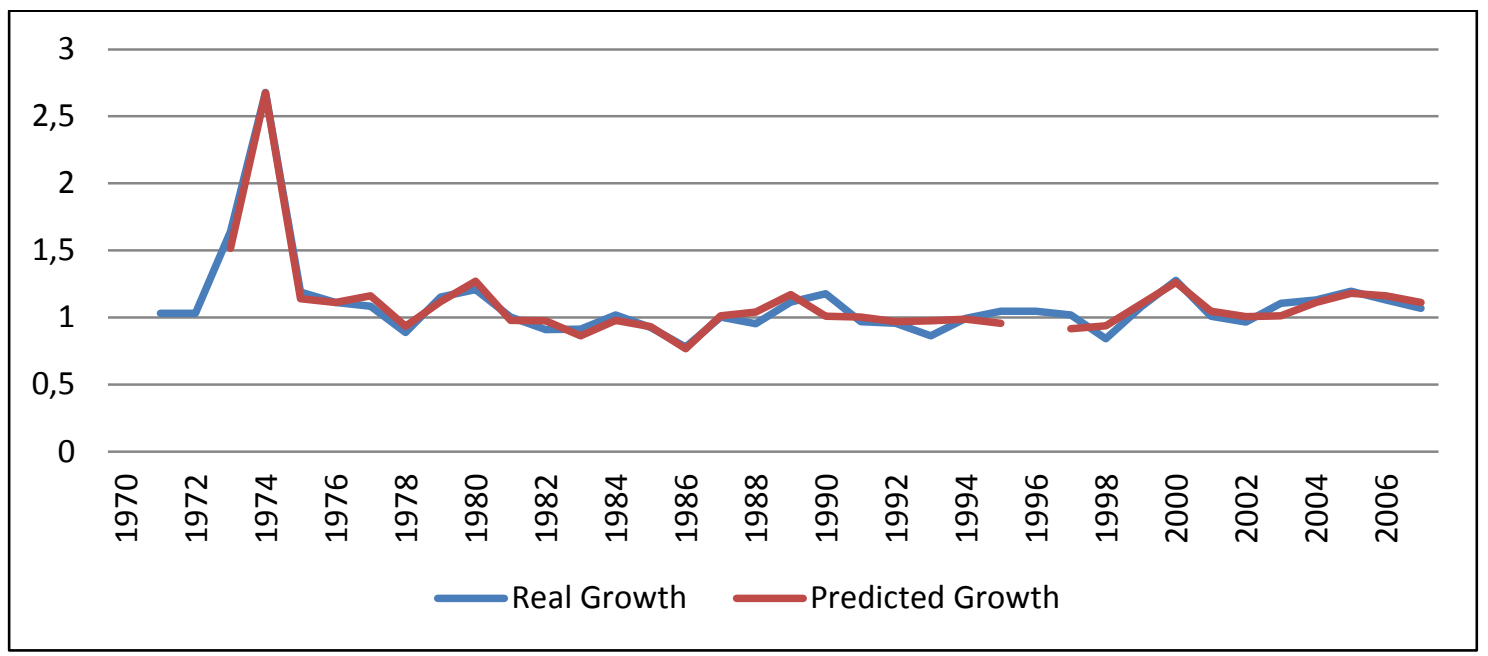

Source: Author calculations.

Overall, the growth model of the UAE corresponds to the assumption and the stylized facts in the past years. The performance of the model is shown in Figure 3. It is clear that the UAE must continue to grow with decreased dependence on the oil sector, as the model explains. Factors that accompany oil sector concentration such as inflation and natural resource abundance only deter prospects of growth because of diminishing marginal returns. Growth will result in the development of other sectors which will naturally display a wider margin of increasing returns. Moving away from reliance on natural resource abundance towards a more evenly distributed allocation of resources is a smarter approach to managing the growth of the UAE economy.

Diversifying the UAE economy in order to support aggregate growth is no simple task. There must be an accurate measure of the determinants of diversification to measure the impact of the particular areas under structural reform. Human capital, labor distribution, privatization, and productive investments are among the prime variables that should be on the agenda to stimulate growth and diversity. 


\section{Economic Diversification in the UAE}

\subsection{Addressing the Oil Curse}

The UAE economy is fueled by oil revenues. This vast amount of natural resource wealth is derived from large scale production and exports, mainly of crude oil, which exceed domestic consumption. The net amount of what is produced to what is consumed, provides great room for oil wealth to accumulate (Al-Khawat, 2008). However, the windfall wealth from oil does not produce effective productivity for the overall UAE economy. The negative impact of TFP is an alarming factor that highlights the pressing need to diversify the UAE economy.

Figure 4: United Arab Emirates Oil Production and Consumption, 2000-2009

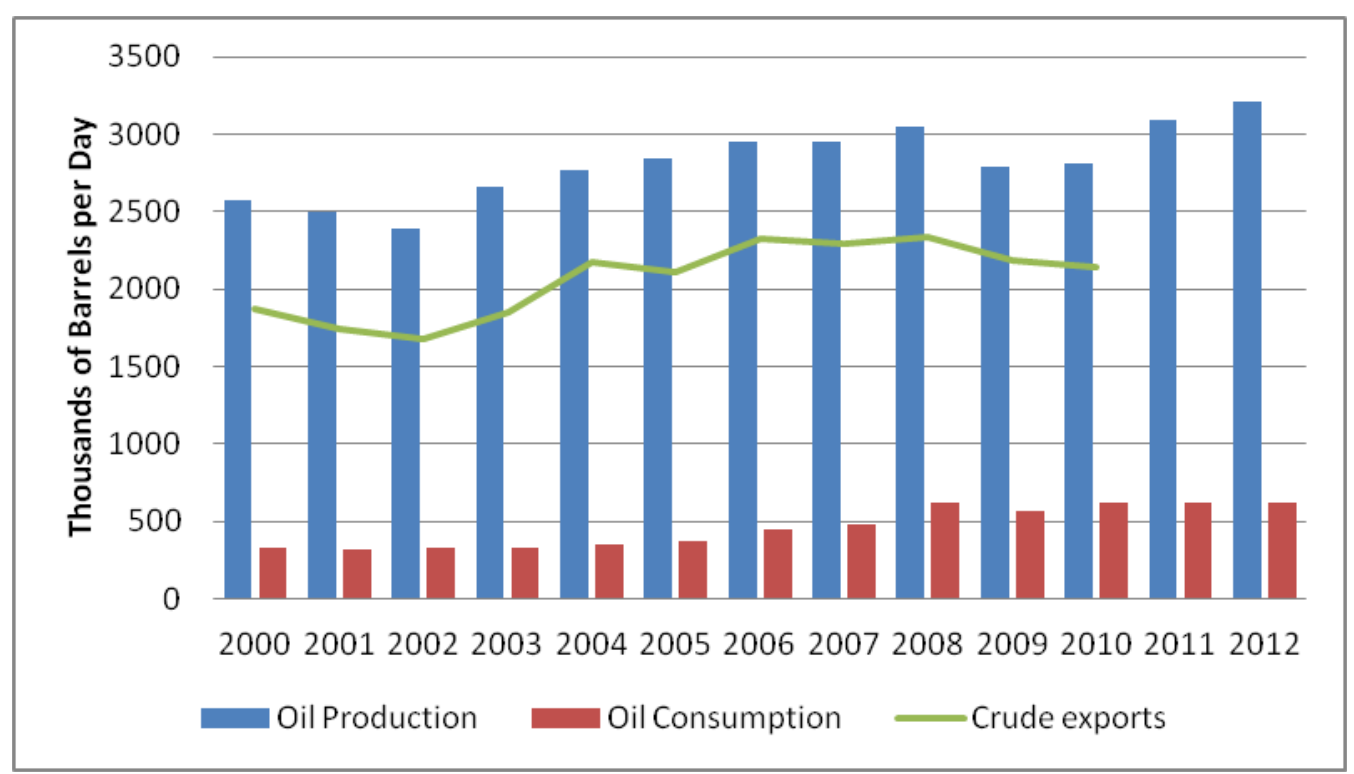

Source: International Energy Statistics, (U.S. Energy Information Administration, 2011)

Fortunately, the UAE is doing just that. Data points to the fact that diversification is on the agenda when it comes to economic and policy decisions. One significant point is that oil production has declined in 2009 by about 300,000 barrels/day. At the same time, crude oil exports declined by about 500,000 barrels/day, while consumption maintained its steady low rates (see Figure 4$)^{8}$. Despite the recent rise in oil export revenue, the overall trend is improving according to data from the International Institute of Finance (Garbis and Abed, 2013).

Some rent appropriators who extract windfall profits from the oil sector are comfortable with sector concentration. The road to diversification will involve difficult politics to convey the importance of decreased concentration on the oil-industry and more productive allocation of resources.

The fact of the matter is that the UAE as a whole benefits from every drop of oil extracted. Whether it be from land rents, the near $50 \%$ tax on oil company revenues, or control over distribution networks, it is clear that the extracted resource is owned by the

\footnotetext{
${ }^{8}$ U.S. Energy Information Administration (EIA), (2011), “United Arab Emirates Country Energy Data, Statistics and Analysis Profile”, International Energy Statistics.
} 
people (Askari and Jaber, 1999). The problem arises when the people of the UAE are set to suffer from the dependency on oil which creates an unproductive economy that is not devoted to human capital.

The analysis of the problem begins with valuating sector concentration. A welldiversified economy has GDP evenly distributed across a wide variety of sectors. The level of concentration among GCC (Gulf Cooperation Council) countries is 26\%, and 16\% among G7 countries (See Abouchakra et al., 2005; and Al-Khawat, 2008).

Sector concentration is not always a bad thing, but generally, the lower the better, as it will indicate an even percentage of sector importance on overall GDP. When analyzing the weight of sectors in GDP, usually nations exercise specialties in which they have a comparative advantage. The problem arises when the sector with the comparative advantage is skewed so heavily in which GDP ultimately becomes defined by the volatility in that one particular sector (hence the oil curse), and has very little room to hedge downfalls to keep the overall economy afoot. The goal is to enforce a better direction for the UAE to avoid this problem in the long run.

Spillovers from the dominant sector in which windfall revenues are allocated to different sectors are no substitute for diversity. This fuzzy logic increases dependency even more for capital distribution that is proven to be non-productive. The other sectors need to be revenue generators of their own, with backing from the dominant sector as a risk cushion against economic slowdown on one side of the balanced GDP spectrum. One way to obtain this balance is through an even distribution of labor among different sectors of the economy by fostering a skilled labor force produced by greater productive investment in the human capital. The bottom line is that this can be done. The UAE should look to countries like Canada and Norway, with abundant natural resource wealth yet booming sub-economies in finance, tourism, and more (Abouchakra et al., 2005) ${ }^{9}$. The UAE has made a good beginning on the right path, but it must sustain this. It should start with decreasing sector concentration as measured by the Normalized-Hirschman Index.

\subsection{Econometric Methods}

The Normalized-Hirschman Index $(\mathrm{NH})$ is used to accurately determine the sector concentration in the UAE. It can be calculated as follows (Al Marhubi, 2000; Naqvi and Morimune, 2005; Ben Hamouda et al., 2006):

$$
N H=\frac{\sqrt{\sum_{i}^{N} P_{i}^{2}}-\sqrt{1 / N}}{1-\sqrt{1 / N}}
$$

where $P$ is $P=\frac{x_{i}}{X}, \mathrm{x}_{\mathrm{i}}$ the value of exports of commodity $\mathrm{i}, X=\sum_{1}^{N} x_{i}$, and $\mathrm{N}$ is the number of products. The NH index is a relative measure of diversity. Its extremes range from 0 to 1 , in which a higher value indicates greater sector concentration. When the $\mathrm{NH}$ index is computed for all GCC countries, the resulting values are around 0.9. This explains that the concentration is very high. The export commodity $i$ is petroleum, as

\footnotetext{
9 Labor productivity in these export based economies shows some strength in the financial sector which was vulnerable to shocks from the global recession. High oil prices helped to neutralize this negative effect. Diversification helps to balance sensitivity to external pressure. Source: Abouchakra et al. (2005).
} 
this is where most of the wealth in the GCC countries is derived from. In order to support the reasoning behind the oil curse, the $\mathrm{NH}$ index was used to show evident concentration in that sector (see Figure 5).

Notice how out of all the GCC economies, the UAE (series 1 ) is the only nation to decrease below GCC norms, with the exception of Qatar (series 5) and Bahrain (series 2). These two outlier nations deserve a closer analysis. According to the United States Bureau of Near Eastern Affairs report on Bahrain (2011), Bahrain's oil reserves are expected to run out in 10-15 years. Perhaps the sharp decrease in its $\mathrm{NH}$ index is a result of declining output. Furthermore, revenues from oil and natural gas account for $10 \%$ of Bahrain's GDP which is $75 \%$ of government income. Bahrain has worked to diversify its economy and stabilize oil production to about 400,000 barrels per day; which is why the NH index has leveled out in the late 1990's. Qatar experienced a sudden drop in its NH index around 1970. This is because of a production decline in oil and a 33\% drop in investment income, again, investment being the variable associated with the decreasing marginal rates of capital return from high sector concentration. Qatar quickly established the Qatar National Petroleum Company to handle oil operations to optimize declining production, but has done little to diversify and face up to the oil curse. The UAE should look to these countries as a model of what not to do.

Figure 5: Normalized-Hirschman index for GCC countries from 1970-2000

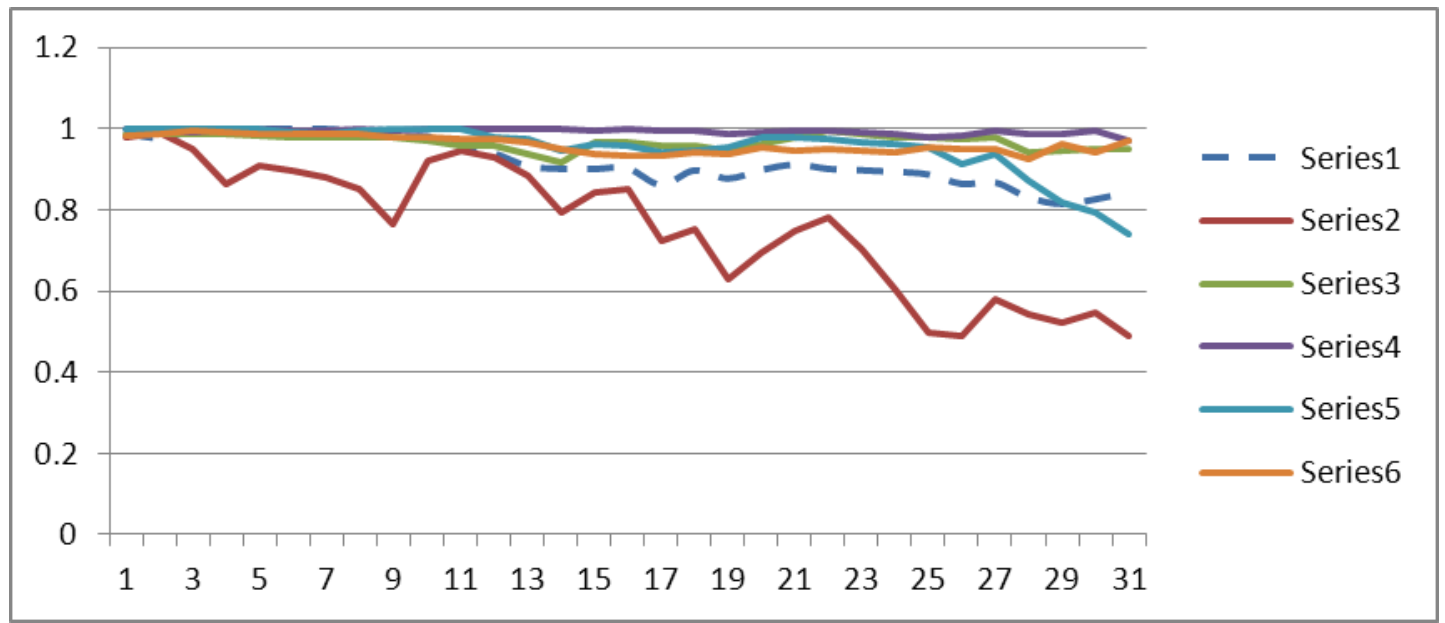

Source: Author calculations. Sample of 21 natural resource and agricultural export products used from 1970 to 2000; subject export product is petrol. The index shows the concentration of the petrol sector in relation to the total sample exports.

Fortunately, as shown in Table 2, non-oil production in the UAE has increased. Real non-oil GDP is also consistently greater than real oil and gas GDP. This shows that despite an increase in oil production, non-oil sectors are continuing to grow. The concentration of sector investment is becoming evenly distributed to support productivity growth. 
Table 2: UAE Selected Macroeconomic indicators, 2005-2010

\begin{tabular}{|c|c|c|c|c|c|c|}
\hline Description & 2005 & 2006 & 2007 & 2008 & 2009 & 2010 \\
\hline Nominal GDP (AED million) & 506.8 & 643.5 & 758.0 & 934.2 & 914.3 & 909.6 \\
\hline GDP (\%) & 30.7 & 27.0 & 17.8 & 23.2 & -2.1 & -0.5 \\
\hline Non-Oil production(sum) & 324.3 & 423.0 & 504.3 & 590.0 & 638.6 & 598.3 \\
\hline (\%) of GDP & 63.9 & 65.7 & 66.5 & 63.2 & 69.8 & 65.8 \\
\hline Oil production (sum) & 182.5 & 220.5 & 253.8 & 344.1 & 275.6 & 311.3 \\
\hline (\%) of GDP & 36.1 & 34.3 & 33.5 & 36.8 & 30.2 & 34.2 \\
\hline Real GDP (at factor price) & 8.2 & 8.7 & 6.1 & 5.1 & -0.7 & 0.6 \\
\hline Real oil \& gas GDP & 1.6 & 6.5 & -2.7 & 1.6 & -6.3 & 2.7 \\
\hline Real non-oil GDP & 10.8 & 9.5 & 9.1 & 6.3 & 1.0 & 0.0 \\
\hline CPI inflation average & 6.2 & 9.3 & 11.6 & 11.5 & 1.0 & 1.5 \\
\hline
\end{tabular}

Source: Global Investment House (2010); IMF (2010); Istatitieh et al. (2007); Kamko Research (2011); and National Bureau of Statistics (2009).

The UAE has decreased its sector concentration, as the NH index declines throughout the years. This supports the claim that economic diversification is in full effect, but further analysis is needed to delve deeper into the determinants of diversification and to see if these results are consistent with the growth model, with the overall goal of increasing TFP.

\subsection{Determinants of Diversification}

As in Ben Hammouda et al. (2006), a statistical model is used to determine the factors which contribute to the economic diversification of the UAE, while also impacting the $\mathrm{NH}$ index. The goal is to increase diversification by decreasing the $\mathrm{NH}$ index. Thus, the $\mathrm{NH}$ index serves as the dependent variable of this model. It is assumed that diversification is a function of different economic and non-economic variables. The basic statistical model is shown in the equation below:

$$
\begin{aligned}
N H_{t}=\alpha_{0}+ & \alpha_{1} \text { ExRate }_{t}+\alpha_{2} \text { GFCC }_{t}+\alpha_{3} \text { GDPC }_{t}+\alpha_{4} \text { Infl }_{t}+\alpha_{5} \text { Invest }_{t} \\
& +\alpha_{6} \text { Trade }_{t}+\varepsilon_{t}
\end{aligned}
$$

where $N H$ index is an index of diversification based on a sample of 1975 to 2006 as the data provides; GFCC is the gross fixed capital formation represented as per cent of GDP; GDPC is GDP per capita; Trade is trade openness; Infl is inflation; and Invest is investment rate. GDP deflator is used instead of CPI as there is more data available for the former; ExRate is exchange rate; $\alpha_{i}$ are the unknown effects to be estimated; and the subscript $t$ is the time index. 
Table 3: Main determinants of Economic diversification (NH) in UAE, 1975-2006.

\begin{tabular}{|l|r|r|r|}
\hline Variables & Coefficient & Std. Error & t-value \\
\hline Constant & 0.91076 & 0.05192 & 17.539 \\
\hline EXCH - Exchange rate & -0.00020 & 0.00145 & -0.139 \\
\hline GDPC - GDP per capita & $6.49 \mathrm{E}-07$ & $2.94 \mathrm{E}-07$ & 2.206 \\
\hline GFCF - Gross fixed capital formation & -0.06704 & 0.00912 & -7.352 \\
\hline INFL - Inflation & 0.00429 & 0.01648 & 0.260 \\
\hline INV - Investment rate & -0.00038 & 0.00094 & -0.400 \\
\hline OPEN - Trade openness & 0.00069 & 0.00035 & 2.006 \\
\hline Adjusted R & & & \\
\hline
\end{tabular}

Some estimated values resulted in insignificant figures (see Table 3). Several alternative model specifications were created to investigate the sensitivity of the significant contribution of the determinants of diversification on the $\mathrm{NH}$ index. However, the reasoning behind the failed attempts could result from the fact that the $\mathrm{NH}$ index is commodity focused, whereas the determinants are macro focused; thereby leaving little room for correlation with the dependent variable in the diversification model. Modeling the determinants of diversification is difficult for several reasons. Running on only 31 data points is not enough to accurately fit the correlation relationship between the determinants and the dependent variable (NH Index).

Despite the addressed errors, the model does shed light on some statistical insight into what the identified determinants of diversification conclude. The goal is for the UAE to try and reduce the concentration index by paying careful attention to the determinants of diversification. The variables that have a negative effect are good for helping to decrease concentration, and the variables with a positive effect will increase concentration and stall diversification. It is explained that a higher exchange rate helps to lower the $\mathrm{NH}$ concentration index.

Higher GDP per capita is on track to raise concentration. With better allocation of oil wealth, GDP per capita will coincide with TFP to have a positive impact on diversification and a negative impact on concentration. Certainly, investments in the human capital to raise GDP per capita and evenly distribute a higher skilled labor force that demands higher pay from the private sector will create a variable that will help to lower the NH concentration.

Higher gross fixed capital formation has helped to lower the $\mathrm{NH}$ concentration, as private investment has picked up, creating an increasingly productive non-oil economy. The goal is to have capital formation evenly distributed among sectors. Fortunately, there is a trend of private capital formation among a wide variety of sectors (especially financials and real estate) to support greater diversification. Because of this, the model has indicated that this variable is set to help decrease the concentration ratio.

This supports the reasoning that macro-economic policies which foster greater economic diversification will eventually decrease the commodity concentration. Policies such as even investment, greater openness, lower inflation to stimulate domestic growth, and a better fiscal balance will help. The pressing need to diversify the economy to avoid an oil curse cannot be stressed enough. The determinants in the diversification and growth model clearly show what needs to be done. So far, it is understood that even labor distribution supports growth, as more skilled workers are evenly situated in various growth sectors. Poor economic diversity results in lower 
productivity and lower competitiveness as there is skewed investment concentration in the dominant sector. Volatile growth in the oil sector poses harm to an economy that is prone to economic cycles, thereby fostering cyclical growth measures evident in the policy decisions of the UAE and its fellow GCC peers (Abouchakra et al. 2005).

As Al-Kawaz (2008) states, "the need for diversification derives, as well, from the very fact that economic management has been concentrated on macroeconomic management issues and neglect, to some extent, the sector issues.” This statement brings attention to the fact that the general wealth landscape relies on the increased concentration on oil.

\section{A Balancing Act}

The UAE economy is highly stable in terms of inflation, exchange rate changes, and openness. It has a good mix of sectors, but must continue to broaden the investment concentration among them. Despite the considerable slowdown in activity they witnessed in 2008 and 2009, the Real Estate and Business Service sectors contributed a sizeable share of $8.4 \%$ to the GDP in 2008 compared to its peak in 2007 where they contributed 9.1\% to the GDP (UAE's national bureau of statistics year book in 2010). The Financial corporation sector has also served as an important element of growth towards the strategy of diversification of the UAE's economy. It contributed $7.1 \%$ of GDP in 2007, attributable mostly to Abu Dhabi and Dubai as their financial sectors represent the majority of the UAE's financial sector at $40.7 \%$ and $41.7 \%$ in 2007 respectively. Yet, due to the financial crisis, financial institutions became constrained as profitability levels and credit conditions shrunk considerably thus leading to a reduction in the ability and readiness of institutions to extend credit facilities. In fact, with the financial crisis witnessed in Dubai 2008, which led its neighbor Abu Dhabi to intervene and provide financial aid, Dubai's financial services share dropped to $39.7 \%$, while Abu Dhabi's rose to $41.4 \%{ }^{10}$.

The contraction in lending activity among the financial services sector along with the sudden shrink in foreign lending was a chief factor in the slowdown in economic activity in 2008. The UAE banking system is well capitalized with leading local banks that are less sensitive to inflationary pressure in the medium term as the oversupplied real estate sector depresses rental prices (QNB, 2012).

Despite the growth in the non-oil sector over the years, it is important to point out that the UAE's oil export earnings and budget surpluses have served as an essential source of funding for the country's large scale public sector infrastructure and development projects that have transformed the UAE into a regional trade hub (Makdisi and Limam, 2000). As a result, the extent to which the UAE will grow in the coming years will likely be influenced by the performance of global oil prices and the demand for oil. We believe that targeted infrastructure projects, investments in human capital, and policies that support Dubai as a regional business hub and thriving service sector economy will help to achieve its goals.

Greater oil revenue is still a major factor, but its effective utilization should be a high priority. Hydrocarbon reserves are still high, and our recent analysis of the global energy market suggest that greater oil exports from the United States could lead to further OPEC caps on oil output, especially as there are no planned oil or gas capacity expansions coming on-stream until 2018 (QNB, 2012).

\footnotetext{
${ }^{10}$ See UAE National Bureau of Statistics, (2009) and National Bureau of Statistics (2010).
} 
Our study also suggests that as the non-Emirati share of the UAE labor force expands, the increased flow of foreign workers will create greater competition and provide an opportunity for more efficient human capital development. The labor market can be a good force of demand that will increase productivity in the non-oil service sectors of the economy. This certainly is a balancing act, but our research indicates that the UAE is taking the right steps. However, policymakers must be aware of the dynamics of a changing economy.

Figure 6: UAE Oil \& Non-Oil GDP contribution by top 3 Emirates in 2008

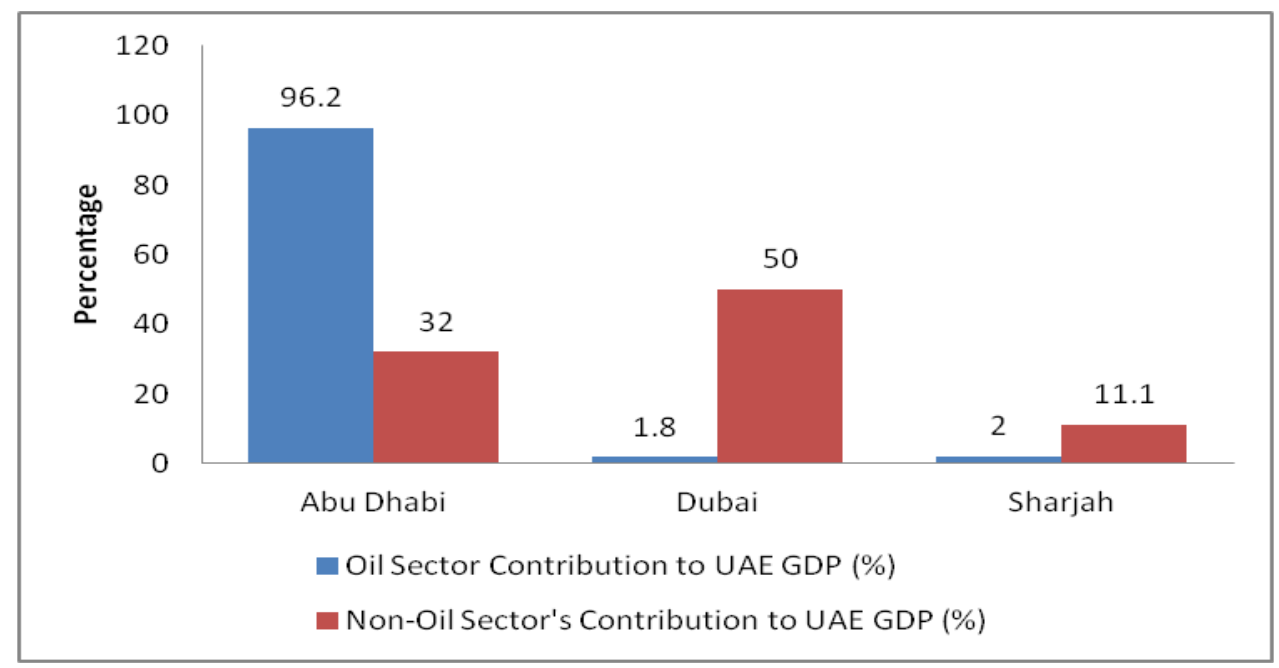

Source: KAMKO Research, (2011)

As oil exports decline in the UAE, the contribution of oil to GDP declines in tandem. As a result, the overall GDP fell just slightly. Figure 6 shows that sector concentration is still evident, but because of the minimal effect on overall GDP from the oil decline, the initial claim that the UAE is diversifying its economy remains consistent. However, because non-oil sectors have become more productive in producing value, overall GDP is saved from relying exclusively on its oil life-line.

\section{Conclusion and Recommendations}

This report finds that the UAE experienced negative consequences from the oil boom that occurred from 2002-2008, and that it is critical that the Emirates focuses on avoiding the oil curse. The consequences are demonstrated by declining total factor productivity rates. These result from inefficient allocation of oil wealth capital, misguided investments with negative marginal returns, a desperately unskilled labor force, and vulnerable pro-cyclical fiscal policy.

In addition, the Government should provide incentives and programs to increase the private sector demand for domestic labor while reducing the size of the Government work force. To accomplish this, greater investments need to be made in education and training for the domestic work force catered to meeting the specific needs of the growing service-based private sector industries. In particular, education/training programs should be aimed at capital intensive sectors such as advanced technology, engineering, construction, finance, and tourism. These industries would especially benefit from the investments to create a highly skilled domestic labor force. 
It is also critical that the Emirates reduces its exposure to outside shocks resulting from the global financial crisis. The UAE is unprepared to withstand these external risks. Consistent with the action plan presented in Elhiraika and Hamed (2007), we reiterate that the UAE needs to take the following steps to increase financial security: (i) Diversifying the UAE economy with an efficient allocation of capital to the non-oil sectors, (ii) Increasing private investment, and (iii) Expanding exports to strategic partners.

To achieve economic diversification and sustainable growth, the domestic financial system should be widened in such a way as to be able to finance increased real domestic investment. In particular, the development of a well-functioning equity market should encourage the return of capital to the country by increasing foreign investments in the UAE that have the added benefit of bringing new technology into the Emirates.

Increasing investments in the private sector, while at the same time decreasing public expenditures, is another method of reducing the risk to the UAE from external shocks. Private investments are significantly more productive than public ones and should increase the Emirates' TFP. This should be accomplished within a framework of reducing public debt, a pre-requisite for sustainable growth. Expanding exports to strategic partners, particularly those with significant capital assets, can also mitigate the impacts of economic shocks outside the control of the UAE. Not only does this increase inward FDI, but it also has the potential for the transfer of high technology to the Emirates. 


\section{References}

Abu Dhabi Economic Vision 2030 (2008), “Section Two, Abu Dhabi's Seven Area of Ongoing Economic: Policy Issues." Abu Dhabi Council for Economic Development and the Department of Planning and Economy, November.

Abouchakra, R., C.N. Moujaes, M.R. Najjar and R. Shediac (2005), "Economic Diversification the Road to Sustainable Development”. Booaz and Co Report.

Al-Marhubi, F. (2000), "Export diversification and growth: an empirical investigation”, Applied Economics Letters 7: 559-562.

Al-Khawat, A. (2008), "Economic Diversification: The case of Kuwait with Reference to Oil Producing Countries”. Journal of Economic Cooperation 29(3): 23-48.

Askari, H. and M. Jaber (1999), "Oil-Exporting Countries of the Persian Gulf: What Happened to all That Money?”, Journal of Energy Finance and Development 4: 185-218.

Barro, R. (1991), "Economic Growth in across-section of Countries," Quarterly Journal of Economics 106(2): 407-433.

Ben Hammouda, H., S. N. Karingi, A. E. Njuguna and M. Sadni-Jallab (2006), "La diversification, Vers un Nouveau Paradigme pour le Développement de l'Afrique”, CAPC, n. 36, Centre Africain de Politique Commerciale.

Bisat, A., El-Erian, M. and T. Helbing (1997), "Growth Investment and Saving in the Arab Countries,” IMF Working Paper WP/97/85.

Elhiraika, A.B. and A. H. Hamed (2007), "Explaining Growth in an Oil-Dependent Economy: The case of The United Arab Emirates", in J. Nugent and H. Pesaran (eds.), Explaining Growth in the Middle East (North Holland/Elsevier, Contributions to Economic Analysis Series).

Fasano, U. (2002), "With open economy and sound policies, U.A.E. has turned oil "curse" into a blessing”, IMF Survey, October, 330-332.

Garbis, I. and G. T. Abed (2013), "Arab Spring, Countries Struggle, GCC Prospects Favorable”, IIF Regional Overview on Middle East and North Africa report, Middle East and Africa Department, Institute of International Finance (IIF), October, 1-42.

Global Investment House (2010), “UAE Economic Outlook 2010”, Global Report, September, 1-41.

Gregorio, J. and P. Guidotti (1995), "Financial development and economic growth", World Development 23 (3): 433-448.

IMF (2011), "United Arab Emirates-2011 Article IV Consultation Concluding Statement”, Article IV Consultation Report, March.

IMF (2010), "United Arab Emirates: 2009 Article IV Consultation-Staff Report. Public Information Notice; and Statement by the Executive Director for United Arab Emirate”, IMF Country Report No. 10/42, February.

IMF (2009), "United Arab Emirates-2009 Article IV Consultation Concluding Statement”, Article IV Consultation Report, March.

Istaitieh, A., S. Hugo, and N. Hussain (2007), "UAE Macroeconomic Report”, Macroeconomic Report Series, Dubai Chamber of Commerce and Industries, Data Management and Business Research Department, 1-52.

Kamco Research (2011), “UAE Economic Brief and Outlook 2011”, Kamco Research Report, April, 1-30.

Makdisi, S. and I. Limam (2000), "Determinants of Growth in the MENA Countries". Paper presented at ERF Workshop held in Cairo, 6-7 April, 2001. 
Ministry of Labor (2000), “The Labor Report: Moving from cheap unskilled labor to skilled labor and advance technology”. Ministry of Labor, Abu Dhabi, UAE. (In Arabic).

Ministry of Planning (1998) "Social and Economic Developments in the United Arab Emirates, 1990-1995”, Abu Dhabi, UAE (in Arabic).

Naqvi, K.H., and K. Morimune (2005). "An Empirical Analysis of the Sustainability of Trade Deficits”, Discussion Paper No. 072, Interfaces for Advanced Economic Analysis, Kyoto University: Kyoto.

National Bureau of Statistics (2009), “Analytical Report on Economic and Social Dimensions in the United Arab Emirates”, Abu Dhabi, April, 1-69

National Bureau of Statistics (2010), “UAE 2010”, UAE year book, 1-284.

National Bureau of Statistics (2010), "Economic Statistics, Price Indices Division”, Abu Dhabi, UAE.

Qatar National Bank (QNB), (2012), “UAE Economic Insight”, Qatar National Bank SAQ Report, 1-50.

Shihab, M. A. (2000), "Growth Accounting with Particular Reference to the UAE". Economic Horizons, 21(83): 15-24.

Solow, R. (1956), “A Contribution to the Theory of Economic Growth,” Quarterly Journal of Economics 70(1): 65-94.

Stanley, D.L. and S. Bunnag (2001), “A new look at the benefits of diversification: lessons from Central America”, Applied Economics 33: 1369-1383.

U.S. Energy Information Administration (EIA), (2011), "United Arab Emirates Country Energy Data, Statistics and Analysis Profile”, International Energy Statistics. 